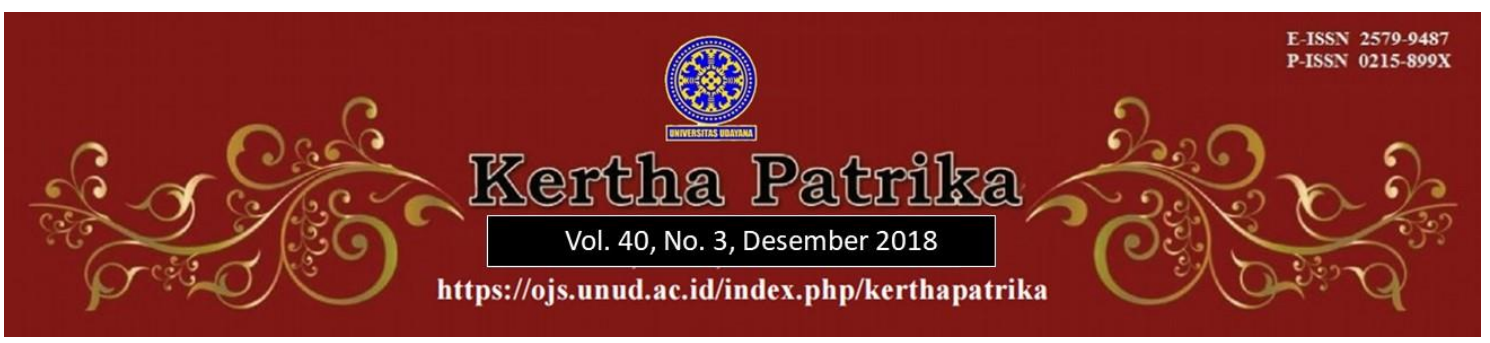

\title{
ANALISIS PEMBUAT, PERBUATAN, DAN TINDAK PIDANA KEKERASAN DALAM RUMAH TANGGA
}

\author{
I Wayan Suardi ${ }^{1}$
}

${ }^{1}$ Kejaksaan Tinggi Bali, E-mail: worksharp@yahoo.com

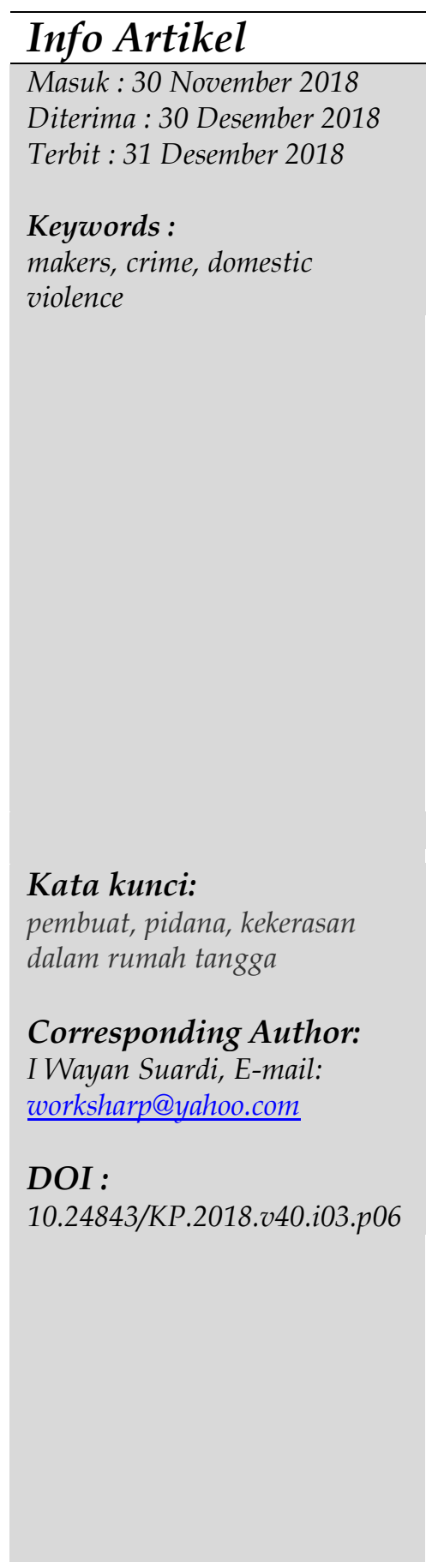

\begin{abstract}
In order to create a harmonious family to avoid various threats of violence depends on the factors of household family members. Self-control and the level of quality of behavior within the family also greatly influence harmony in the family. Domestic violence is a form of a criminal action that enters the private sphere. The purpose of this paper is to identify the concept of maker, action, and crime in the regulations governing domestic violence. This writing applies normative legal research method that analyzes the vagueness of norms related to the maker, actions, crime in Law Number 23 of 2004 concerning the Elimination of Domestic Violence. This study uses a statutory approach and a legal concept-analysis approach. The analysis of legal material in this study uses descriptive analysis techniques. This study concluded that the problems appeared in the implementation of the Law on the Elimination of Domestic Violence in the judiciary is caused by the regulation of the Law on the Elimination of Domestic Violence which was inaccurate, unclear, multiple interpretations and not systematic. As a consequence, law enforcement officials, especially judges, need to interpret the contents of the provisions of the law in trying a real case.
\end{abstract}


dikarenakan pengaturan UU Penghapusan KDRT yang tidak cermat, tidak jelas, multitafsir, dan tidak sistematis. Sebagai konsekuensinya, aparat penegak hukum, khususnya hakim, perlu menafsirkan isi ketentuan undang-undang tersebut dalam mengadili suatu perkara konkrit.

\section{Pendahuluan}

Kekerasan Dalam Rumah Tangga (KDRT) secara etimologis terdiri dari kekerasan dan dalam rumah tangga. Kekerasan memiliki makna penderitaan atau melakukan suatu derita, yang berarti perilaku seseorang manusia atau kelompok manusia yang berdampak pada suatu penderitaan terhadap orang lain baik pribadi maupun kelompok. Pendapat Michael Levi tentang suatu kekerasan sebagai “... its content and cuase are socially constructed". Jerome Skolncik mengartikan suatu tindak kekerasan atau violence sebagai "... an ambiguous term whose meaning is established throught political process." 1 Dilihat dari pandangan kedua ahli tersebut tampak bahwa perumusan tindak kekerasan sangatlah tidak manusiawi dan juga kejam, perumusan tersebut juga diadopsi dari hasil aspirasi kaum perempuan dan anak yang selalu rentan terhadap kekerasan itu sendiri. Rumah tangga juga dilihat secara etimologis yang artinya adalah ikatan lahir batin pria dengan wanita dengan tujuan membentuk suatu keluarga berdasarkan Ketuhanan Yang Maha Esa. Hal tersebut telah sesuai dengan inti dari Pasal 1 Undang-Undang Nomor 1 Tahun 1974 tentang Perkawinan. ${ }^{2}$

Negara Indonesia menjamin keadilan, persamaan, dan keamanan, untuk tiap-tiap warga negaranya seperti perlindungan baik pribadi maupun keluarga, harta benda, rasa aman, bebas dari ancaman ketakutan dalam melakukan atau tidak melakukan suatu perbuatan, itu semua adalah hak asasi dari seseorang. Apabila kerukunan dan keutuhan rumah tangga terganggu karena pengendalian diri manusia yang tidak dapat dikontrol maka akan menyebabkan terjadinya kekerasan dalam rumah tangga oleh salah satu anggota keluarga hingga timbulnya rasa ketidakadilan dan ketidak amanan dalam rumah tangga. Adanya keberlakuan Undang-Undang Nomor. 23 Tahun 2004 Tentang Penghapusan Kekerasan Dalam Rumah Tangga (selanjutnya disebut UU Penghapusan KDRT), penerapan hukum sebagai dasar bagi aparat penegak hukum khususnya oleh kepolisian, kejaksaan, dan hakim dalam menjatuhkan sanksi, masih menjadi suatu persoalan apakah penerapannya dengan UU Penghapusan KDRT atau dengan mengacu ketentuan hukum yang lainnya. ${ }^{3}$

Bentuk tindak pidana ini memberikan konsekuensi kepada penegak hukum terutama Hakim untuk mengetahui konstruksi yuridis tindak pidananya agar ketika mendapatkan perkara yang konkrit dapat mudah mempertimbangkan dan memutusnya. Kekerasan dalam rumah tangga yang terjadi di masyarakat, tindakan hukum yang dapat diterapkan dengan Pasal 26 ayat (1) UU Penghapusan KDRT yang

1 Passalbessy, J. D. (2010). Dampak Tindak Kekerasan Terhadap Perempuan Dan Anak Serta Solusinya. Jurnal Sasi, 16(3). h. 9

2 Nadya, I., \& Firdaus, E. (2015). Penyelesaian Tindak Pidana Kekerasan dalam Rumah Tangga Berdasarkan Restorative Justice oleh Kepolisian Sektor Kandis. Jurnal Online Mahasiswa Fakultas Hukum Universitas Riau, 2(2). h. 2.

3 Karya, D. (2013). Tindak Pidana Kekerasan dalam Rumah Tangga yang Dilakukan Suami terhadap Istri (Studi Kasus di Pengadilan Negeri Gresik). DIH: Jurnal Ilmu Hukum, 9(17). h. 83. 
menyatakan bahwa setiap orang yang menjadi pihak korban dapat memberikan suatu kuasa baik terhadap keluarga maupun orang lain baik pada tempat korban berada atau di tempat kejadian perkara, agar dapat melaporkan adanya suatu tindak kekerasan dalam lingkup rumah tangga kepada pihak aparat penegak hukum yakni pihak kepolisian. Proses pelaporan dapat dilakukan oleh wali, pengasuh, orang tua bahkan anak itu sendiri apabila yang menjadi korban adalah seorang anak sesuai dengan peraturan perundang-undangan yang berlaku.

Berdasarkan penjelasan latar belakang tersebut adapun permasalahan yang dibahas dalam tulisan ini adalah pertama bagaimanakah analisis terhadap pembuat dan bentuk-bentuk perbuatan tindak pidana dalam UU Penghapusan KDRT dan bagaimanakah ketentuan pidana dan pemidanaan terhadap tindak pidana dalam UU Penghapusan KDRT tersebut. Hasil studi dari Tjokorda Istri Putra Astiti pada tahun 2014 mengkaji tentang sinkronisasi dan diferensiasi putusan hakim dalam penyelesaian kasus-kasus kekerasan dalam rumah tangga. ${ }^{4}$ Berkaitan dengan kekerasan dalam rumah tangga, Hermanes Delfim Alves Silva pada tahun 2017 mengkaji tentang tanggung jawab kepolisisan Timor Leste terhadap kekerasan dalam rumah tangga di kota Dili. ${ }^{5}$ Karya ilmiah ini bertujuan untuk mengkualifisir beberapa permasalahan dalam penerapan UU Penghapusan KDRT, pengkualifikasian permasalahan tersebut dengan mendasarkan pada tiga segi dari hukum pidana yakni segi pembuat, perbuatan dan pidana.

\section{Metode Penelitian}

Jenis penelitian hukum normatif digunakan pada penulisan karya ilmiah ini. Fokus kajian berangkat dari kekaburan norma pada UU Penghapusan KDRT dikarenakan pengaturan undang-undang tersebut tidak cermat, tidak jelas, multitafsir, dan tidak sistematis. Penelitian ini menggunakan beberapa pendekatan yaitu pendekatan peraturan tentang perempuan dalam Kitab Undang-Undang Hukum Pidana (selanjutnya disebut KUHP) dan juga menggunakan pendekatan analitical $\mathcal{E}$ conceptual approach yaitu dalam pendekatan konsep hukum ini akan dilihat kesenjangan yang terjadi dalam peraturan perundang-undangan yang diteliti, dimana konsepsi hukum merupakan dasar untuk menyusun konsep tentang bagian-bagian tertentu dari hukum dan cara menentukan instrumen keilmuan dalam melakukan penelitian dan analisis hukum. ${ }^{6}$ Teknik analisis bahan hukum menggunakan teknik deskriptif dianalisis secara sistematis yang dipaparkan dalam bentuk uraian-uraian yang berhubungan dengan teori ataupun asas hukum yang terdapat dalam hukum pidana sehingga memperoleh suatu kesimpulan dan gambaran yang jelas dalam pembahasan masalah.

\section{Hasil dan Pembahasan}

\subsection{Pembuat dan Bentuk Perbuatan Tindak Pidana KDRT}

Perempuan dan anak yang paling banyak atau rentan sebagai korban kekerasan dalam rumah tangga wajib untuk memperoleh suatu perlindungan agar bebas dari segala

${ }^{4}$ Astiti, T. I. P. (2014). Sinkronisasi dan Diferensiasi Putusan Hakim dalam Penyelesaian Kasuskasus Kekerasan dalam Rumah Tangga. Jurnal Magister Hukum Udayana (Udayana Master Law Journal), 3(2). h. 346

5 Silva, H. D. A. (2017). Tanggungjawab Kepolisian Timor Leste terhadap Kekerasan dalam Rumah Tangga di Kota Dili. Masalah-Masalah Hukum, 46(2). h. 248

6 Putra, I. B. W. (2016). Teori Hukum Dengan Orientasi Kebijakan. Denpasar: Udayana University Press. h. 54 
bentuk ancaman kekerasan, kekerasan, perlakuan yang tidak manusiawi dan penyiksaan. Tetapi, dari hal tersebut bukan berarti korban KDRT adalah porsinya hanya untuk perempuan dan lebih lanjut tidak berarti perempuan tidak bisa menjadi pelaku tindak pidana KDRT. Bahwa perempuan (yang hendak dilindungi UU Penghapusan KDRT) bisa menjadi pelaku tindak pidana KDRT terlihat dari:

1. Asas penghapusan KDRT yakni Nondiskriminasi dalam ketentuan Pasal 3 huruf c UU Penghapusan KDRT.

2. Cara perumusan tindak pidana KDRT tersebut dalam Bab VIII UU Penghapusan KDRT, yaitu dengan awalan kata : "Setiap orang". Rumusan setiap orang ini yang dimaksud adalah merujuk pada jenis kelamin perempuan atau laki-laki.

3. Dilihat dari perumusan tentang korban KDRT, yakni setiap orang yang baik mengalami ancaman kekerasan atau kekerasan di dalam lingkup rumah tangga diantaranya istri, suami, juga anak. Orang-orang yang karena perkawinan, pengasuhan, persusuan, hubungan darah, dan juga perwalian serta orang yang membantu bekerja dalam rumah tangga dan menetap tinggal dalam rumah tangga itu sendiri.

Perempuan yakni isteri bisa menjadi subjek atau pelaku tindak pidana KDRT dan karenanya "laki-laki yakni suami" menurut undang-undang ini dapat juga menjadi korban dari KDRT. Ketentuan ini harus dibaca dan diterapkan secara berimbang, jangan sampai apabila pelaku KDRT adalah laki-laki (suami) maka penyidik menerapkan pasal-pasal tindak pidana dalam UU Penghapusan KDRT, sedangkan apabila pelaku KDRT adalah perempuan (isteri) penyidik tidak menerapkan pasalpasal dalam UU Penghapusan KDRT misalnya pasal dalam KUHP.

Masalah "pembuat" kekerasan dalam rumah tangga ini penting, oleh karena jangan sampai timbul pemikiran UU Penghapusan KDRT hanya diperuntukkan bagi laki-laki (suami), sehingga apabila perempuan (isteri) melakukan KDRT hanya dijerat dengan ketentuan penganiayaan pada Pasal 351 KUHP. Pada konteks ini, perlu adanya penerapan yang seimbang dari UU Penghapusan KDRT. Meskipun jiwa undangundang ini untuk melindungi perempuan, tetapi dalam aturan pasalnya juga memberikan hak yang sama kepada laki-laki yakni suami untuk dilindungi.

Berdasarkan ketentuan Pasal 5 UU Penghapusan KDRT terdapat adanya empat jenis tindak pidana yang dijadikan bentuk KDRT adalah berupa kekerasan seksual, kekerasan psikis, kekerasan fisik dan yang terakhir yaitu penelantaran rumah tangga. Kekerasan fisik jenis tindak pidana yang pertama dapat dilihat pada Pasal 6 UU Penghapusan KDRT yaitu melakukan kekerasan fisik yang diartikan sebagai suatu perbuatan berdampak pada rasa yang sakit, atau luka berat dan jatuh sakit. Pengertian tersebut jika dibandingkan dengan pengertian penganiayaan dalam Pasal 351 KUHP yaitu perbuatan mengakibatkan luka-luka berat, dan penganiayaan disamakan sengaja merusak kesehatan, serupa tapi tidak sama. Penganiayaan merupakan perbuatan yang sengaja membuat perasaan tidak enak atau penderitaan.

Ketentuan penganiayaan ringan pada KUHP mensyaratkan harus terdapat unsur dengan sengaja menimbulkan perasaan tidak enak (penderitaan), rasa sakit (pijn) atau luka, dan yang terpenting pada syarat lanjutannya adalah menimbulkan penyakit atau halangan dalam menjalankan mata pencaharian pekerjaan. Dengan demikian jika ditafsirkan secara otentik pengertian "kekerasan fisik" yang dianut dalam UU 
Penghapusan KDRT lebih sempit daripada pengertian dari "penganiayaan" KUHP, oleh karena menimbulkan suatu penderitaan atau perasaan tidak enak, luka dan dapat merusak kesehatan orang itu tidaklah terkualifikasi sebagai "kekerasan fisik" dalam Pasal 6 UU Penghapusan KDRT.

Permasalahan lain muncul karena ternyata dalam UU Penghapusan KDRT tidak terdapat pengertian atau penjelasan dari frasa "rasa sakit, jatuh sakit dan luka berat". Pengertian atau penjelasan tersebut paling penting untuk dapat membuktikan jenis perbuatan mana yang dilakukan oleh terdakwa itu sendiri. Karenanya mau tidak mau kita harus mencari pengertian-pengertian tersebut dalam KUHP dan yurisprudensi.

Rasa sakit hanya cukup bahwa orang lain merasa sakit tanpa ada ciri-ciri perubahan dalam bentuk fisik. Rasa sakit, contohnya seperti menampar, memukul, mencubit. Jatuh sakit yaitu adanya suatu gangguan fungsi dari organ-organ tubuh di dalam tubuh manusia. Luka berat yaitu luka yang terkualifikasi dalam Pasal 90 KUHP yakni jatuh sakit yang berpotensi tidak memberikan kesempatan atau harapan untuk sembuh dan juga dapat menyebabkan kematian. Kehilangan salah satu dari panca indera, tidak mampu menjalankan tugas pekerjaan, cacat, lumpuh, gugur atau matinya kandungan dari seorang perernpuan. Akibat "penganiayaan" dalam UU Penghapusan KDRT tidak disebutkan sebagai "kekerasan fisik" yaitu luka yang terdapat perubahan dalam bentuk fisik manusia yang berlainan dari pada bentuk semula.

Ketentuan pidana untuk perbuatan kekerasan fisik yakni yang tercantum dalam Pasal 44 UU KDRT, maka kekerasan fisik ini terbagi dalam 3 bentuk yakni:

\section{Kekerasan fisik biasa}

Pasal 44 ayat 1 UU Penghapusan KDRT menyatakan bahwa setiap orang yang melakukan perbuatan kekerasan fisik dalam lingkup rumah tangga dipidana dengan pidana penjara paling lama lima tahun atau denda paling banyak lima belas juta rupiah.

Jika melihat ketentuan Pasal 5 huruf a jo. Pasal 6 UU Penghapusan KDRT maka perbuatan terlarang dalam pasal 44 ayat (1) ini adalah perbuatan mengakibatkan "rasa sakit, jatuh sakit, atau luka berat", tetapi jika kita melihat aturan dalam Pasal 44 ayat 2 UU Penghapusan KDRT yang mengatur tentang kekerasan fisik yang menyebabkan jatuh sakit atau luka berat, maka maksud pasal 44 ayat 1 UU Penghapusan KDRT hanya mengancam atas perbuatan yang mengakibatkan "rasa sakit saja". Dari hal ini terlihat perumusan pengertian, aturan dan ancaman perbuatan "kekerasan fisik" UU Penghapusan KDRT tidak sinkron dan tidak sistematis.

Ketentuan yang dilarang dalam Pasal 44 ayat (1) UU Penghapusan KDRT ini adalah setiap orang yang dengan sengaja melakukan perbuatan yang menimbulkan rasa sakit pada korban (dalam lingkup rumah tangga) yakni korban merasa sakit tanpa ada perubahan dalam bentuk badan. Konstruksinya "penganiayaan" jelas syarat tersebut harus ada, tetapi dalam UU Penghapusan KDRT ada hal yang berbeda yakni dengan adanya ketentuan dalam Pasal 44 ayat 4 UU Penghapusan KDRT (tentang kekerasan fisik ringan).

Konsekuensi dari hal tersebut jelas jika kekerasan fisik itu dilakukan bukan atau selain oleh suami terhadap isteri atau sebaliknya dan tidak menimbulkan penyakit atau 
halangan untuk menjalankan pekerjaan maka harus tetap dipidana dengan Pasal 44 ayat (1) UU Penghapusan KDRT terkualifikasi sebagai kekerasan fisik biasa. Dengan demikian, kekerasan fisik dalam Pasal 44 ayat (1) UU Penghapusan KDRT syaratnva adalah harus ada perbuatan yang menimbulkan rasa sakit dan menimbulkan penyakit atau halangan untuk menjalankan pekerjaan jabatan atau mata pencaharian atau kegiatan sehari-hari.

Apabila kekerasan fisik dilakukan oleh bukan atau selain oleh suami terhadap isteri atau sebaliknya maka syaratnya cukup hanya ada perbuatan yang menimbulkan rasa sakit. Jadi sedikit membingungkan dan berbeda kualifikasi kekerasan fisik dengan "penganiayaan", apakah konstruksinya memang dibuat demikian atau memang ada kesalahan dalam penyusunannya. Tapi karena aturannya demikian penegak hukum harus memegang konstruksi hukum "kekerasan fisik" dalam pasal 44 ayat (1) tersebut. Lebih lanjut, "kekerasan fisik" dalam pasal 44 ayat (1) akibatnya hanya menimbulkan "rasa sakit". Maka bukan merupakan KDRT atau kekerasan fisik apabila ada ayah yang melakukan perbuatan yang membuat perasaan tidak enak kepada anak. Lebih janggal lagi bukan merupakan KDRT jika ayah mengiris, memotong, menusuk dengan pisau anak dan anak mengalami luka tetapi tidak menimbulkan jatuh sakit. Konstruksi tersebut demikian karena perasaan tidak enak dan luka tidak terkualifikasi sebagai kekerasan fisik.

Hal demikian terasa janggal, tetapi itulah aturannya dalam UU Penghapusan KDRT, sehingga hal ini memberi kesempatan kepada aparat penegak hukum khususnya Hakim untuk memberikan penafsiran apakah tetap menganut faham otentik UU Penghapusan KDRT atau memberikan roh baru pada pengertian "kekerasan fisik" yakni termasuk pula di dalamnya "perasaan tidak enak" dan "luka". Atau memberikan penafsiran baru yang tidak membedakan antara "rasa sakit" dengan "perasaan tidak enak" terutama dengan "luka".

Penjelasan di atas menunjukkan bahwa UU Penghapusan KDRT terlalu ceroboh memberikan pengertian otentik atas kekerasan fisik yang tidak lengkap, sebagaimana tertuang di dalam Pasal 6 UU Penghapusan KDRT, sehingga menyulitkan dalam penerapannya. Lebih lanjut, kualifikasi dalam Pasal 44 ayat (1) UU Penghapusan KDRT ini tidak menampung apabila terjadi kasus "kekerasan fisik yang direncakan terlebih dahulu", apakah hal ini akan tetap diajukan sebagai KDRT atau digunakan aturan KUHP yakni Pasal 353 KUHP tentang penganiayaan berencana.

Jika digunakan UU Penghapusan KDRT maka diperlukan terobosan oleh Hakim untuk memaknai frasa "melakukan perbuatan" dalam pasal 44 ayat (1) UU Penghapusan KDRT ini dalam konstruksi baik direncanakan atau tidak direncanakan.

2. Kekerasan fisik ringan (delik aduan).

Pasal 44 ayat 4 UU Penghapusan KDRT menyatakan bahwa kekerasan fisik yang dilakukan oleh suami terhadap isteri atau isteri terhadap suami yang menekankan pada tidak menimbulkan penyakit atau halangan untuk menjalankan pekerjaan jabatan atau mata pencaharian atau kegiatan sehari-hari.

Apabila seorang ayah hanya menampar anaknya dan setelah ditampar anak tersebut tetap bisa bermain, perbuatan ayah tersebut bukan melakukan "kekerasan fisik ringan (Pasal 44 ayat (4) UU Penghapusan KDRT)" tetapi "kekerasan fisik biasa (44 ayat (1) UU Penghapusan KDRT)". Meskipun konstruksi hukumnya berbeda, KUHP dalam 
Pasal 356 ayat (1) memberikan pemberatan pidana jika terjadi penganiayaan yang dilakukan oleh suami terhadap isteri atau sebaliknya, tetapi dalam KDRT justru hal ini menjadi unsur yang meringankan.

3. Kekerasan fisik mengakibatkan korban jatuh sakit atau luka berat

Pasal 44 ayat (2) UU Penghapusan KDRT, perbuatan terlarang dalam hal ini melakukan perbuatan yang berakibat mendapatkan jatuh sakit (timbul gangguan atas fungsi dari alat-alat di dalam badan manusia) atau luka berat dalam lingkup rumah tangga (kualifikasinya dalam Pasal 90 KUHP). Terlihat jika memang pengertian jatuh sakit dan luka berat dalam pasal ini sesuai dengan pengertian dalam KUHP, maka penempatan akibat perbuatan ini tidak sepadan, karena "jatuh sakit" dan "luka berat" merupakan akibat yang secara kualitas sangat jauh berbeda, tetapi dalam pasal ini diancam dengan pidana yang sama.

Konstruksi pasal ini karena ada frasa "mengakibatkan korban" maka "jatuh sakitnya atau luka beratnya korban" hanya merupakan akibat yang tidak dimaksud oleh si pelaku. Dengan demikian menjadi masalah jika terjadi kasus kekerasan fisik yang mengakibatkan orang tersebut jatuh sakit atau luka beratnya korban adalah yang disengaja oleh pelaku tersebut. Kekerasan fisik yang “jatuh sakit atau luka beratnya korban" adalah dimaksud dan direncanakan lebih dahulu oleh pelaku. Apabila terjadi kasus demikian, apakah ketentuan Pasal 44 ayat (2) UU Penghapusan KDRT dapat diberlakukan. Jika merujuk pada rumusan pasal 44 ayat (2) UU Penghapusan KDRT maka kasus di atas bukan kualifikasi pasal tersebut karena menurut Pasal 44 ayat (2) jatuh sakit/luka berat hanya merupakan akibat bukan dimaksud apalagi direncanakan.

4. Kekerasan fisik mengakibatkan matinya korban (Pasal 44 ayat (3) UU Penghapusan KDRT)

Pasal 44 ayat (3) UU Penghapusan KDRT menyatakan bahwa perbuatan sebagaimana dimaksud pada ayat (2) mengakibatkan matinya korban. Perbuatan terlarang ini adalah melakukan kekerasan fisik yang menyebabkan orang kehilangan nyawanya dalam lingkup rumah tangga. Dimana oleh karena dalam rumusan pasal tersebut ada frasa "mengakibatkan matinya korban" yaitu hanya rnerupakan akibat yang tidak dikehendaki oleh si pelaku tersebut.

Sama dengan permasalahan dalam Pasal 44 ayat (4) UU Penghapusan KDRT, jika terdapat kasus-kasus seperti; kekerasan fisik yang "matinya" korban adalah dimaksud atau disengaja oleh pelaku atau ada kekerasan fisik yang "matinya" korban adalah dimaksud dan direncanakan lebih dahulu oleh pelaku, maka ketentuan Pasal 44 ayat (3) UU Penghapusan KDRT tidak dapat diberlakukan.

Kasus tersebut tentunya akan membawa 2 (dua) dampak yakni :

1. Kasus di atas tetap sebagai KDRT dengan cara Hakim memberikan penafsiran bahwa "mengakibatkan matinya korban" ini dimaksudkan baik "sebagai maksud atau disengaja, sebagai akibat, atau sebagai maksud yang telah direncanakan".

2. Kasus tersebut tidak merupakan KDRT. Aparat penegak hukum menggunakan KUHP agar dapat menyelesaikan perkara tersebut, yakni jika matinya adalah dimaksud/disengaja pelakuberlakukan Pasal 354 ayat (2) KUHP, apabila luka berat dimaksud atau disengaja dan direncakan lebih dahulu diberlakukan Pasal 355 ayat (2) KUHP. 
Hal-hal di atas menunjukkan perumusan tindak pidana dalam UU Penghapusan KDRT tidak terlalu jelas. Tugas berat ada di pundak penegak hukum khususnya hakim untuk memperbaiki hal tersebut. Lebih lanjut, dalam UU Penghapusan KDRT tidak jelas diatur mengenai bentuk percobaan atas "kekerasan fisik", dalam arti apakah percobaan atas kekerasan fisik dan percobaan atas kekerasan ringan dapat dipidana, oleh karena dalam KUHP jelas percobaan melakukan penganiayaan dan penganiayaan ringan tidak dapat dipidana. Hal ini sesuai dengan ketentuan Pasal 351 ayat (2) KUHP yang menentukan bahwa jika perbuatan mengakibatkan luka-luka berat, yang bersalah diancam dengan pidana penjara paling lama lima tahun. Kemudian Pasal 352 yaitu kecuali yang tersebut dalam Pasal 353 dan 356, maka penganiayaan yang tidak menimbulkan penyakit atau halangan untuk menjalankan pekerjaan jabatan atau pencarian, diancam, sebagai penganiayaan ringan, dengan pidana penjara paling lama tiga bulan atau pidana denda paling banyak empat ribu lima ratus rupiah. Pidana dapat ditambah sepertiga bagi orang yang melakukan kejahatan itu terhadap orang yang bekerja padanya, atau menjadi bawahannya.

Berdasarkan uraian di atas terlihat aturan dalam UU Penghapusan KDRT yang mengatur tentang "kekerasan fisik" banyak celah dan menimbulkan banyak interpretasi. Hal ini berbeda dengan bentuk dan kualifikasi "penganiayaan" dengan KUHP yang relatif jelas dan lengkap karena mencakup segala bentuk penganiayaan. Seperti pada Pasal 351 (1) Penganiayaan diancam dengan pidana penjara paling lama dua tahun delapan bulan atau pidana denda paling banyak empat ribu lima ratus rupiah. (2) Jika perbuatan mengakibatkan luka-luka berat, yang bersalah diancam dengan pidana penjara paling lama lima tahun. (3) Jika mengakibatkan mati, diancam dengan pidana penjara paling lama tujuh tahun. (4) Dengan penganiayaan disamakan sengaja merusak kesehatan. (5) Percobaan untuk melakukan kejahatan ini tidak dipidana.

Pasal 352 (1). Kecuali yang tersebut dalam Pasal 353 dan 356, maka penganiayaan yang tidak menimbulkan penyakit atau halangan untuk menjalankan pekerjaan jabatan atau pencarian, diancam, sebagai penganiayaan ringan, dengan pidana penjara paling lama tiga bulan atau pidana denda paling banyak empat ribu lima ratus rupiah. Pidana dapat ditambah sepertiga bagi orang yang melakukan kejahatan itu terhadap orang yang bekerja padanya, atau menjadi bawahannya. (2) Percobaan untuk melakukan kejahatan ini tidak dipidana.

Pasal 353 (1). Penganiayaan dengan rencana lebih dahulu, diancam dengan pidana penjara paling lama empat tahun. (2) Jika perbuatan itu mengakibatkan luka-luka berat, yang bersalah dikenakan pidana penjara paling lama tujuh tahun. (3) Jika perbuatan itu mengakibatkan kematian, yang bersalah diancam dengan pidana penjara paling lama sembilan tahun.

Pasal 354 (1). Barang siapa sengaja melukai berat orang lain, diancam karena melakukan penganiayaan berat dengan pidana penjara paling lama delapan tahun. (2) Jika perbuatan itu mengakibatkan kematian, pihak yang bersalah diancam dengan pidana penjara paling lama sepuluh tahun.

Pasal 355 (1). Penganiayaan berat yang dilakukan dengan rencana terlebih dahulu, diancam dengan pidana penjara paling lama dua belas tahun. (2) Jika perbuatan itu mengakibatkan kematian, yang bersalah diancam dengan pidana penjara paling lama lima belas tahun.

Pasal 356. Pidana yang ditentukan dalam Pasal 351, 353, 354 dan 355 dapat ditambah dengan sepertiga: 1 . bagi yang melakukan kejahatan itu terhadap ibunya, bapaknya 
yang sah, istrinya atau anaknya; 2. jika kejahatan itu dilakukan terhadap seorang pejabat ketika atau karena menjalankan tugasnya yang sah; 3. jika kejahatan itu dilakukan dengan memberikan bahan yang berbahaya bagi nyawa atau kesehatan untuk dimakan atau diminum.

Pasal 356 ke-1 KUHP yang terdapat hukuman tambahan 1/3 kepada pelaku penganiayaan terhadap bapak, anak, ibu dan istri. Rancangan Undang-Undang KUHP Pasal 487 menambahkan kata suami merupakan pasal-pasal yang mengaitkan dengan kekerasan dalam rumah tangga artinya pasal tersebut sebenarnya bukan diberlakukan khusus untuk memperoleh sanksi terhadap pelaku KDRT saja, melainkan juga tindak penganiayaan lain yang sifatnya umum. ${ }^{7}$

Kekerasan psikis, jenis tindak pidana yang kedua ini adalah kekerasan psikis yang termuat pada ketentuan Pasal 7 UU Penghapusan KDRT. Muncul suatu permasalahan dalam UU Penghapusan KDRT, yakni tidak ditemukan pengertian yang paling penting untuk membuktikan jenis perbuatan yang dilakukan oleh terdakwa yaitu pengertian dari "hilang rasa percaya diri, ketakutan, rasa tidak berdaya, penderitaan psikis yang berat. Dengan tidak adanya pengertian dan batasan yang lengkap, maka kesulitan akan muncul dalam hal pembukiannya.

Beban pembuktikan hal tersebut dapat diberikan dalam bentuk visum psikiatrium. Visum tersebut merupakan permintaan dari penyidik agar seorang dokter mengeluarkan surat keterangan mengenai hasil dari pemeriksaan medik manusia, baik hidup atau mati ataupun bagian yang diduga dari tubuh manusia, untuk kepentingan peradilan berdasarkan keilmuannya dan di bawah sumpah. ${ }^{8}$ Berdasarkan Peraturan Menteri Kesehatan Republik Indonesia Nomor 77 Tahun 2015 Tentang Pedoman Pemeriksaan Kesehatan Jiwa Untuk Kepentingan Penegakan Hukum, khususnya Pasal 2 yang menyatakan bahwa "visum et repertum psikiatrikum adalah hasil pemeriksaan kesehatan jiwa oleh dokter jiwa pada seseorang di fasilitas pelayanan kesehatan untuk kepentingan penegakan hukum yang berbentuk surat."

Kekerasan seksual, jenis tindak pidana yang ketiga adalah sesuai dengan ketentuan Pasal 8 UU Penghapusan KDRT. Kekerasan seksual dalam ketentuan ini intinya perbuatan yang berupa pemaksaan hubungan seksual kepada orang lain dengan cara yang tidak wajar atau bertujuan komersil.

UU Penghapusan KDRT menganut hal yang berbeda jika dibandingkan dengan KUHP. Adanya istilah kekerasan seksual terhadap orang yang menetap dalam lingkup rumah tangga. Jadi adanya potensi kekerasan seksual oleh suami kepada isteri atau sebaliknya. Dengan adanya kata "pemaksaan" kekerasan seksual, tidak dapat ditemukan penjelasan tersebut dalam UU Penghapusan KDRT.

Kejahatan yang sejenis dengan "kekerasan seksual" adalah "perkosaan" dalam KUHP. KUHP terdapat frasa "dengan kekerasan atau ancaman kekerasan memaksa", sedangkan dalam UU Penghapusan KDRT hanya "pemaksaan dan memaksa" saja. Di

7 Yanik, W. N. (2007). Penyelesaian Tindak Pidana Kekerasan dalam Rumah Tangga dengan Dasar Pasal 356 Ke-1 KUHP (Studi Kasus di Pengadilan Negeri Klaten) (Doctoral Dissertation, Univerversitas Muhammadiyah Surakarta). h. 6.

8 Soeparmono, R. (2002). Keterangan Ahli E Visum et Repertum dalam Aspek Hukum Acara Pidana. Bandung: Mandar Maju. h. 34 
sini kembali Hakim dibebani oleh UU Penghapusan KDRT untuk dapat menafsirkan kembali, dengan melihat pengertian perkosaan pada Pasal 285 KUHP, maka "pemaksaan dan memaksa" disini harus di konstruksikan sebagai "memaksa baik dengan cara ancaman kekerasan maupun dengan kekerasan". Lebih lanjut yang harus diperhatikan adalah karena dalam kekerasan seksual mensyaratkan "pemaksaan" maka bukan merupakan KDRT yakni kekerasan seksual jika pelaku melakukan hubungan seksual karena suka sama suka atau dengan cara membujuk. Contoh kasus bukan merupakan KDRT jika orang tua (suami atau isteri) melakukan persetubuhan dengan anaknya apabila persetubuhan itu dilakukan suka sama suka atau dengan cara membujuk. Apabila terjadi kasus demikian maka harus diselesaikan dengan KUHP dan UU Perlindungan Anak, kalau korbannya adalah anak dibawah umur sesuai dengan ketentuan Pasal 1 angka 2 Undang-Undang Nomor 35 Tahun 2014 Tentang Perubahan Atas Undang-Undang Nomor 23 Tahun 2002 Tentang Perlindungan Anak yang menyatakan bahwa Perlindungan Anak adalah segala kegiatan untuk menjamin dan melindungi Anak dan hak-haknya agar dapat hidup, tumbuh, berkembang, dan berpartisipasi secara optimal sesuai dengan harkat dan martabat kemanusiaan, serta mendapat perlindungan dari kekerasan dan diskriminasi.

Penelantaran rumah tangga, jenis tindak pidana yang keempat ini adalah penelantaran orang dalam lingkup rumah tangga yang diancam pidana dalam Pasal 49 UU Penghapusan KDRT. Bahwa unsur penting dalam jenis tindak pidana ini adalah frasa "menelantarkan ", dimana UU Penghapusan KDRT tidak memberikan pengertian tentang hal ini, berbeda dengan "kekerasan fisik, psikis dan seksual" yang diberikan pengertian secara normatif. Karenanya diperlukan penafsiran secara sistematis, Pasal 49 UU Penghapusan KDRT ini berkaitan erat dengan ketentuan Pasal 9 UU Penghapusan KDRT.

Berdasarkan hal tersebut maka pengertian atau kualifikasi dari perbuatan "menelantarkan", terwujud dalam pengertian tidak memberikan perawatan, hak untuk mendapatkan kehidupan yang layak dalam rumah tangga, melarang orang untuk bekerja di dalam atau di luar rumah sehingga korban berada di bawah tekanan, juga pemeliharaan kepada orang.

Frasa "perawatan, atau pemeliharaan kepada orang, tidak memberikan kehidupan,", perumusannya hanya pada "perbuatannya". Akibat dari "penelantaran" tersebut tidak disinggung sama sekali, padahal menurut Penulis point penting unsur ini adalah harus menimbulkan "terlantarnya orang". Apabila perumusannya hanya berorientasi pada "perbuatan" saja, maka pasal ini termasuk pasal karet, contoh kasus apabila suami yang pengangguran (tidak berpenghasilan) meninggalkan isterinya yang seorang PNS (berpenghasilan) selama 1 (satu) bulan, maka menurut pasal 49 UU Penghapusan KDRT, suami yang tidak berpenghasilan dapat dikenakan pasal ini oleh karena dia meninggalkan isterinya selama 1 bulan (tidak memberikan perawatan/pemeliharaan) padahal faktanya menunjukkan isteri tidak mungkin terlantar karena dia punya penghasilan sendiri, malah mungkin dalam kasus ini suaminya yang terlantar.

Masalah tersebut muncul karena perumusan "menelantarkan" hanya menunjuk kepada "perbuatannya" sedangkan aspek "akibat penelantarannya" tidak disinggung sama sekali. Karenanya kedepan untuk memudahkan menentukan adanya perbuatan 
dari "menelantarkan" maka haruslah dikaitkan pula dengan akibat dari perbuatan "menelantarkan" tersebut yakni "korban terlantar".

\subsection{Pidana dan Pemidanaan Terhadap Tindak Pidana KDRT}

Suatu sanksi pidana seyogyanya dijatuhkan secara seimbang atau proporsional, artinyapemidanaan suatu delik tidak boleh berlebihan, hal tersebut sesuai dengan asas keseimbangan dalam hukum pidana. ${ }^{9}$ Setelah melalui proses pemeriksaan perkara dan terdakwa telah terbukti secara sah dan meyakinkan bersalah melakukan tindak pidana KDRT maka pidana harus dijatuhkan oleh majelis Hakim. Dalam masalah pemidanaan, UU Penghapusan KDRT memberiksan suatu asas bahwa dalam penghapusan KDRT selain untuk menindak pelaku, juga untuk memelihara keutuhan rumah tangga sesuai dengan ketentuan Pasal Pasal 4 UU Penghapusan KDRT.

Tataran normatif dan empirik, Hakim dalam mewujudkan suatu keseimbangan untuk memelihara keutuhan rumah tangga yang harmonis telah diimplementasikan "keseimbangan" tersebut pada Pasal 44 ayat (4) UU Penghapusan KDRT, apabila terjadi kekerasan fisik yang dilakukan oleh suami terhadap isteri atau sebaliknya yang tidak menimbulkan penyakit atau halangan maka hal ini dijadikan alasan untuk meringankan tindak pidana tersebut. Berbeda dengan Pasal 356 ayat (1) KUHP yang merupakan pemberatan pidana apabila penganiayaan dilakukan oleh suami atau istri dan sebaliknya. UU Penghapusan KDRT ini merupakan suatu aturan yang meringankan terdakwa jika terjadi pemidanaan, pidananya cenderung lebih ringan, dan perkawinan pelaku dan korban diharapkan tidak terjadi perceraian.

Apabila orang tua (suami/isteri) memukul anaknya, hal tersebut terkualifikasi sebagai "kekerasan fisik biasa" yang bukan merupakan delik aduan, kalaupun ada perdamaian antara korban (anak) dan pelaku (orang tua) bukan alasan untuk menghentikan perkara, dalam kasus seperti ini dimungkinkan keutuhan rumah tangga yang harmonis dan sejahtera tidak akan tercapai. Sehingga kedepan harus ada perbaikan mengenai rumusan "kekerasan fisik ringan" bukan saja jika dilakukan oleh "suami terhadap isteri atau sebaliknya" tetapi juga oleh "setiap orang dalam lingkup rumah tangga".

UU Penghapusan KDRT memberikan sarana kepada Hakim untuk "menyeimbangkan penindakan dan keutuhan rumah tangga" yakni dalam Pasal 50 UU Penghapusan KDRT. Hakim dalam menghukum pelaku KDRT dapat menjatuhkan pidana tambahan berupa pembatasan gerak pelaku dan penetapan pelaku mengikuti program konseling.

Penjelasan Pasal 50 UU Penghapusan KDRT dimaksudkan untuk memberikan kebebasan kepada Hakim menjatuhkan pidana percobaan. Dengan demikian, UU Penghapusan KDRT memberikan sarana agar tercapai "keseimbangan" dalam penanganan perkara KDRT, hakim memberikan pidana berupa pidana percobaan dengan hukuman tambahan berupa Terdakwa mengikuti lembaga konseling.

Pidana dalam bentuk tersebut sangat kasuistis dan tidak bisa diterapkan sepenuhnya dalam bentuk KDRT yang lain. Akhirnya kembali diperlukan upaya yang sungguhsungguh dan Hakim untuk menyeimbangkan antara menindak pelaku KDRT dengan

\footnotetext{
9 Bakhri, S. (2011). Pengaruh Aliran-Aliran Falsafat Pemidanaan dalam Pembentukan Hukum Pidana Nasional. Jurnal Hukum Ius Quia Iustum, 18(1). h. 144
} 
memelihara keutuhan rumah tangga yang harmonis dan sejahtera. Putusan Hakim yang berupa pemidanaan hendaknya tidak menghancurkan lembaga perkawinan dan tidak menghancurkan kelangsungan hidup orang yang ada dalam perkawinan tersebut khususnya terhadap anak. Jangan sampai anak-anak mengalami kerugian sosial, fisik, maupun mental karena mereka sesungguhnya dilindungi oleh Convention on the Rights of the Child (Konvesi Hak Anak/KHA) yang telah diratifikasi oleh Indonesia melalui Keputusan Presiden Nomor 36 Tahun $1990^{10}$ serta melalui UU Perlindungan Anak yang melindungi anak-anak dari berbagai bentuk perlakuan kekerasan dalam rumah tangga. ${ }^{11}$

\section{Kesimpulan}

Permasalahan berkaitan dengan penerapan UU Penghapusan KDRT dalam peradilan dikarenakan pengaturan UU Penghapusan KDRT yang tidak cermat, tidak jelas, multitafsir, dan tidak sistematis. Sebagai konsekuensinya, aparat penegak hukum, khususnya hakim, diberikan beban untuk menafsirkan isi ketentuan UU Penghapusan KDRT tersebut apabila menemukan perkara konkrit. Terhadap hal ini, pemerintah hendaknya merumuskan peraturan yang dapat memberi pegangan kepada Hakim untuk menjatuhkan pidana yang "seimbang"dalam menindak pelaku KDRT. Oleh karena menjaga agar rumah tangga tidak tercerai berai merupakan jiwa dan amanat dari UU Penghapusan KDRT, aparat penegak hukum, dalam hal ini hakim, hendaknya tidak hanya mengutamakan pertimbangan yuridis semata, tetapi harus perlu memperhatikan aspek sosial sosial dan kepentingan nasib korban kekerasan terutamanya tentang masa depan anak.

\section{Daftar Pustaka}

\section{Buku}

Putra, I. B. W. (2016). Teori Hukum Dengan Orientasi Kebijakan. Denpasar: Udayana University Press.

Soeparmono, R. (2002). Keterangan Ahli \& Visum et Repertum dalam Aspek Hukum Acara Pidana. Bandung: Mandar Maju.

\section{Jurnal}

Astiti, T. I. P. (2014). Sinkronisasi dan Diferensiasi Putusan Hakim dalam Penyelesaian Kasus-kasus Kekerasan dalam Rumah Tangga. Jurnal Magister Hukum Udayana (Udayana Master Law Journal), 3(2).

Bakhri, S. (2011). Pengaruh Aliran-Aliran Falsafat Pemidanaan dalam Pembentukan Hukum Pidana Nasional. Jurnal Hukum Ius Quia Iustum, 18(1).

Karya, D. (2013). Tindak Pidana Kekerasan dalam Rumah Tangga yang Dilakukan Suami terhadap Istri (Studi Kasus di Pengadilan Negeri Gresik). DIH: Jurnal Ilmu Hukum, 9(17).

\footnotetext{
10 Megawati Barthos, S. H. (2012). Perlindungan Hukum Terhadap Anak Dalam Kekerasan Rumah Tangga Menurut Uu No. 23 Tahun 2002 Tentang Perlindungan Anak (Studi Kasus Putusan No. 1500/Pid. B/2005/Pn. Tng). Constitutum, 12(1). h. 462

11 Raflis, R. I., Rochaeti, N., \& Wijaningsih. D. (2016). Perlindungan Hukum Bagi Pekerja Rumah Tangga Perempuan Korban Tindak Kekerasan. Diponegoro Law Lournal. 5(3). h. 3.
} 
Megawati Barthos, S. H. (2012). Perlindungan Hukum Terhadap Anak Dalam Kekerasan Rumah Tangga Menurut Uu No. 23 Tahun 2002 Tentang Perlindungan Anak (Studi Kasus Putusan No. 1500/Pid. B/2005/Pn. Tng). Constitutum, 12(1).

Nadya, I., \& Firdaus, E. (2015). Penyelesaian Tindak Pidana Kekerasan dalam Rumah Tangga Berdasarkan Restorative Justice oleh Kepolisian Sektor Kandis. Jurnal Online Mahasiswa Fakultas Hukum Universitas Riau, 2(2).

Passalbessy, J. D. (2010). Dampak tindak kekerasan terhadap perempuan dan anak serta solusinya. Jurnal Sasi, 16(3).

Raflis, R. I., Rochaeti, N., \& Wijaningsih. D. (2016). Perlindungan Hukum Bagi Pekerja Rumah Tangga Perempuan Korban Tindak Kekerasan. Diponegoro Law Jo.urnal. 5(3).

Silva, H. D. A. (2017). Tanggungjawab Kepolisian Timor Leste terhadap Kekerasan dalam Rumah Tangga di Kota Dili. Masalah-Masalah Hukum, 46(2).

\section{Tesis atau Disertasi}

Yanik, W. N. (2007). Penyelesaian Tindak Pidana Kekerasan dalam Rumah Tangga dengan Dasar Pasal 356 Ke-1 KUHP (Studi Kasus di Pengadilan Negeri Klaten) (Doctoral Dissertation, Univerversitas Muhammadiyah Surakarta).

\section{Peraturan Perundang-Undangan}

Undang-Undang Nomor 1 Tahun 1974 Tentang Perkawinan, Lembaran Negara Republik Indonesia Tahun 1974 Nomor 1, Tambahan Lembaran Negara Nomor 3019

Undang-Undang Nomor 23 Tahun 2004 Tentang Penghapusan Kekerasan Dalam Rumah Tangga, Lembaran Negara Republik Indonesia Tahun 2004 Nomor 95, Tambahan Lembaran Negara Republik Indonesia Nomor 4419

Undang-Undang Nomor 35 Tahun 2014 Tentang Perubahan Atas Undang-Undang Nomor 23 Tahun 2002 Tentang Perlindungan Anak, Lembaran Negara Republik Indonesia Tahun 2014 Nomor 297, Tambahan Lembaran Negara Republik Indonesia Nomor 5606

Keputusan Presiden Nomor 36 Tahun 1990 Tentang Pengesahan Convention On The Rights Of The Child (Konvensi Tentang Hak-Hak Anak), Lembaran Negara Republik Indonesia Tahun 1990 Nomor 57

Peraturan Menteri Kesehatan Republik Indonesia Nomor 77 Tahun 2015 Tentang Pedoman Pemeriksaan Kesehatan Jiwa Untuk Kepentingan Penegakan Hukum, Berita Negara Republik Indonesia Nomor 1861, 2015 